\title{
Evaluation of long-range transport and deposition of desert dust with the CTM MOCAGE
}

\author{
By M. MARTET ${ }^{1,2 *}$, V.-H. PEUCH ${ }^{2}$, B. LAURENT ${ }^{3}$, B. MARTICORENA ${ }^{4}$ \\ and G. BERG AMETTI ${ }^{4}, \quad{ }^{1}$ Météo France, DP/Serv/Env, France; ${ }^{2}$ Météo-France and CNRS, CNRM-GAME \\ URA1357, France; ${ }^{3}$ Leibniz Institute for Tropospheric Research, Leipzig, Germany; ${ }^{4}$ CNRS and Universities Paris 7 \\ and 12, LISA UMR7583, France
}

(Manuscript received 21 February 2008; in final form 28 November 2008)

\begin{abstract}
Desert dust modelling and forecasting attract growing interest, due to the numerous impacts of dusts on climate, numerical weather prediction, health, ecosystems, transportation, as well as on many industrial activities. The validation of numerical tools is a very important activity in this context, and we present here an example of such an effort, combining in situ (horizontal visibility in SYNOP messages, IMPROVE database) and remote-sensing data (satellite imagery, AERONET aerosol optical thickness data). Interestingly, these measurements are available routinely, and not only in the context of dedicated measurements campaign; thus, they can be used in an operational context to monitor the performances of operational forecasting systems. MOCAGE is the chemistry-transport model of Météo-France, used operationally to forecast the three-dimensional transport of dusts and their deposition. Two very long-range transport episodes of dust have been studied: one case of Saharan dust transported to East America through Asia and Pacific observed in November 2004 and one case of Saharan dust transported from West Africa to Caribbean Islands in May 2007. Episodes of geographical extension had seldom been studied, and they provide a very selective reference to compare the modelled desert dusts with. The representation of dusts in MOCAGE appears to be realistic in these two very different cases. In turn, the model simulations are used to make the link between the complementary information provided by the different measurements tools, providing a fully consistent picture of the entire episodes. The evolution of the aerosol size distribution during the episodes has also been studied. With no surprise, our study underlines that deposition processes are very sensitive to the size of dust particles. If the atmospheric cycle, in terms of mass, is very much under the influence of larger particles (some micrometres and above), only the finer particles actually travel over thousands of kilometres. This illustrates the need for an accurate representation of size distributions for this aerosol component in numerical models and advocates for using a size-resolved (bin) approach as sinks, and particularly, deposition do not affect the emitted log-normal distributions symmetrically on both sides of the median diameter. Overall, the results presented in this study provide an evaluation of Météo-France operational dust forecasting system MOCAGE.
\end{abstract}

\section{Introduction}

Dust emitted from desert surfaces by wind erosion of soil can be transported in the atmosphere over thousands of kilometres (i.e. Asian dust over the Pacific Ocean, Gong et al., 2006; Zhao et al., 2006 or African dust over the Atlantic Ocean, Prospero and Carlson, 1972; Colarco et al., 2003a,b). This mineral aerosol plays a preponderant role during their transport in the atmosphere: due to their radiative properties, these particles impact on the Earth radiative budget (Sokolik et al., 2001) and the climate system or on numerical weather prediction (Chaboureau

\footnotetext{
* Corresponding author.

e-mail: maud.martet@meteo.fr

DOI: $10.1111 / \mathrm{j} .1600-0889.2008 .00413 . x$
}

et al., 2007). There is also a sanitary impact of dust on human health especially through their capability to be a vector for some virus or bacteria (some researches are exploring the potential for climate/environmental models to predict the probability of occurrence of meningitis epidemics; Thomson et al., 2006). Their deposition on infrastructures impacts several industrial activities (solar panels, transportation, etc.). Moreover, their deposition in some limited-nutrient ecosystems (open ocean, tropical forest) represent a significant supply in Phosphorus or Iron for these environments (Swap et al., 1992; Bergametti et al., 1992; Jickells et al., 2005).

Modelling is an efficient tool to study or forecast the evolution of dust concentration in the atmosphere. Though it is not a new research topic (for instance DEAD, Zender et al., 2003, or DREAM, Nickovic et al., 2001 models), there is increased 
interest today, also in the context of the GMES program in Europe (Global Monitoring for Environment and Security) or with the development of the Sand and Dust Storm Research Development Project (Sand and Dust Storm Warning and Assessment System; SDS-WAS) of the World Meteorological Organization.

MOCAGE is the chemitry-transport model of Météo-France (see for instance Josse et al., 2004; Dufour et al., 2004; Nho et al., 2005; Bousserez et al., 2007), and it is used to represent the three-dimensions transport of dust. Though MOCAGE has a multiscale option, the configuration used here is global with an horizontal resolution of $2^{\circ} \times 2^{\circ}$ and 47 vertical levels (from the surface to $5 \mathrm{hPa}$ ). MOCAGE dynamics are driven in this study by meterological analysis (winds, temperature, pressure, humidity) coming from Météo-France's operational global model ARPEGE. Transport is computed by a semi-Lagrangian scheme for all species (Josse et al., 2004), turbulent diffusion is accounted for following (Louis, 1979) and MOCAGE convection is parametrized with a mass flux scheme, described in Bechtold et al. (2001). It can represents both gaseous and aerosols species simultaneously, but the present work relies only on the aerosol part of the model. Aerosols are considered as an external mix and a sectional approach has been chosen (see the following). For the present work focusing on dusts, phenomena such as growth, coagulation and nucleation have been neglected. Particles are separated in bins following their diameter, and each bin is considered as a passive tracer, aerosols concentrations vary following depositions (wet and dry), sedimentation, emission and transport. In this paper, MOCAGE is used to study two very long-range transport episodes of dusts. In November 2004, a very particular situation has been observed: Saharan dusts have been transported easterly, passed through Asia and Pacific Ocean and reached the Western America. In May 2007, Martinique has been confronted with a heavy dust cloud. These particles have been transported from Africa to Caribbean islands. These situations are frequent, but such an intensity had never been observed in Martinique. These two episodes are good cases to evaluate the results of our model.

\section{Aerosol representation in MOCAGE}

\subsection{Dust emissions}

Desert dusts emission fluxes mainly depend of wind velocity and on the surface features (Marticorena and Bergametti, 1995). Thus, modelling of dust is primarily dependent on how the emissions are represented. MOCAGE has been coupled with a module of dynamic source of dust emissions described in (Marticorena et al., 1997; Laurent et al., 2005, 2006). This emissions module mainly accounts for the effects of the soil size distribution, surface roughness and soil moisture (Fécan et al., 1999). In this study, since we focus on the impacts of Saharan dust, only Saharan dust emissions are considered. Precisely, emissions are simulated for an area covering Sahara, the Arabian peninsula and the Middle East $\left(36^{\circ} \mathrm{N}-12^{\circ} \mathrm{N} ; 17^{\circ} \mathrm{W}-78^{\circ} \mathrm{E}\right)$. Over this area, the aerodynamic roughness length has been calculated from a geomorphologic study based on topographic, geological, pedologic and climatologic information (Callot et al., 1990). The horizontal resolution of this aerodynamic roughness length is $1^{\circ} \times 1^{\circ}$. In our simulations, surface wind velocity coming from ARPEGE analysis are used. Dust emissions are calculated over a $1^{\circ} \times 1^{\circ}$ resolution and are summed over $2^{\circ} \times 2^{\circ}$ grid cells. The initial size distribution is a three-mode log-normal distribution. The mean diameters and the standard deviations for these three modes are, respectively, 1.5, 6.7, $14.2 \mu \mathrm{m}$ and 1.7, 1.6, 1.5.

Following (Ginoux et al., 2004), the annual emission from North Africa is around $1400 \mathrm{Tg} \mathrm{yr}^{-1}$, which represents $65 \%$ of the global emission. Studying the emissions modelled by MOCAGE for the meteorological year 2000, major known areas of emissions appearat Mauritania, Bodele depression, south of Egypt and south of the Arabic peninsula. In all these areas, there are more than $200 \mathrm{~d}$ of emissions (Fig. 1a). This geographical repartition is consistent with Middleton and Goodie (2001). The frequency of days $\times$ gridpoints emissions has been calculated for every month of the year 2000 (Fig. 1b); from March to August, the emissions are more frequent than during the rest of the year $(+38.5 \%$ in June, $-49 \%$ in November $)$. The link between dust emissions and meteorological conditions implies that the position of the Inter-Tropical Convergence Zone (ITCZ) modifies the emissions. This phenomenon leads to the interseasonal cycle of dust emissions over North Africa.

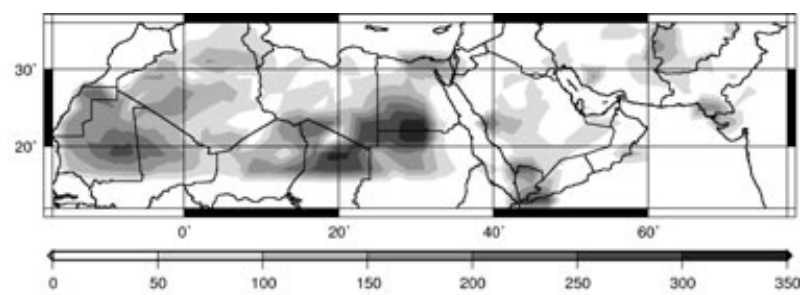

(a)

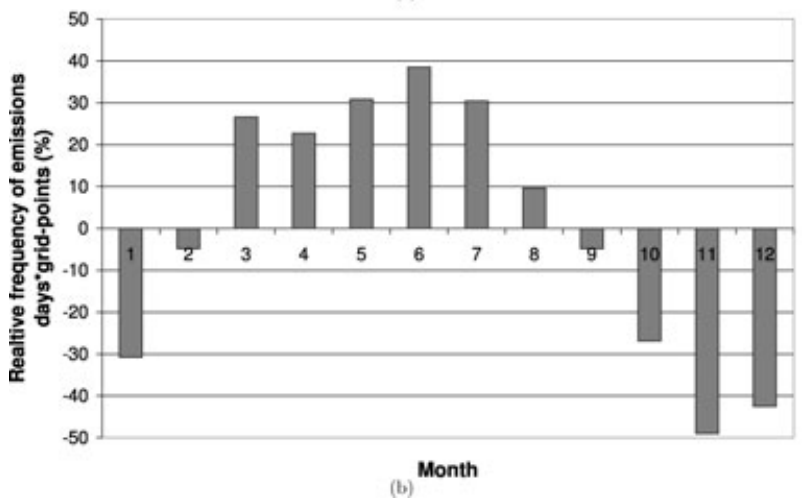

Fig. 1. Statistical characteristics of emissions on the African zone. a) Number of days of emission during 2000. b) Relative frequency of emission days $\times$ grid-points during 2000 . 


\subsection{Management of the aerosol size distribution}

The main phenomenathat rule the behaviour of aerosols in the atmosphere-scavenging, sedimentation and deposition on surfaces - depend on the size of the particles (Lunt and Valdes, 2002). To represent aerosol size distribution in aerosol models, two approaches are commonly used: the 'sectional' one, which separates the particles in bins according to their size (Wexler et al., 1994; Jacobson, 1997; Meng et al., 1998), and the 'log-normal' one, which assumes that the mass or number size distribution can be represented by probability distribution function, generally a log-normal law (Binkowski and Shankar, 1995; Ackermann et al., 1998). The main advantage of the log-normal approach is to be able to represent aerosol distribution considering only three moments for each mode. On the other hand, the sectional one is able to describe with user chosen precision the aerosol size distributions, at the cost of increased CPU/MEM required for the models. No assumption is made in the case of bins regarding the shape of the distributions, which is an advantage regarding the aging of dust particles affected differentially by sinks according to the size (see the following).

The sectional approach has been chosen for the present study. Considering a log-normal initial distribution, $\bar{D}_{g}$ is the mean diameter and $\sigma_{g}$ the geometrical standard deviation. To separate this distribution of $N$ particles in bins, we have to determine the fraction of particles included between $D_{i, l}$ and $D_{i, u}$ :

$S_{i}=\bar{F}\left(D_{i, u}\right)-\bar{F}\left(D_{i, l}\right)=\frac{1}{2}\left[\operatorname{erf}\left(D_{i, u}\right)-\operatorname{erf}\left(D_{i, l}\right)\right]$

where $\bar{F}(D)$ is the normalized cumulative function

$\bar{F}(D)=\frac{1}{2}+\frac{1}{2} \operatorname{erf}\left(\frac{\ln D-\ln \bar{D}_{g}}{\sqrt{2} \ln \sigma_{g}}\right)$

and $\operatorname{erf}$ is the error function :

$\operatorname{erf}(z)=\frac{2}{\sqrt{\pi}} \int_{0}^{z} \mathrm{e}^{-\eta^{2}} \mathrm{~d} \eta$

Then we can define the mass of aerosol included between $D_{i, l}$ and $D_{i, u}$, considering $D_{i}$ as the mean diameter and $\rho$ the volumique mass:

$m_{i}=N \times S_{i} \times \frac{\pi}{6} D_{i}^{3} \times \rho$.

This sectional approach requires to define the number of bins and the average particle diameter for these different bins.

Increasing the number of bins is a way to assess the shortcomings of using reduced and more computationaly tractable number of bins. But, this implies an augmentation of the CPU needed, which is detrimental in an operational context. Another way to improve the description of the aerosol concentrations is to adapt the size of the bins to the efficiency of the sinks. To improve the representation of the aerosol sinks, it is important to describe more precisely the aerosol size distribution where the sinks are more efficient. Studying the impact of the particle size on the sinks, an optimization of the number and the size of the bins has been implemented.

It is important to have an accurate description not only where the concentrations are high but also where the phenomena are efficient. Wet deposition considers coagulation in the cloud (Langner and Rodhe, 1991) and depends on the precipitation rate, the cloud water content and the transfer efficiency of aerosol in precipitation. These parameters are not linked with the aerosol size. Under the cloud, impaction of droplets following Chaumerliac (1984) and Seinfeld et Pandis (1998) to calculate the efficiency of collision between particles and droplets are used. Scavenging rate is the product of this efficiency of collision $(E)$ and the colllision volume $\left(V_{\text {col }}\right)$.

$$
\begin{aligned}
V_{\mathrm{col}}= & \frac{\pi\left(D_{g}+D_{p}\right)^{2}}{4} \times\left[U_{t}\left(D_{g}\right)-u_{t}\left(D_{p}\right)\right], \\
E= & \frac{4}{\operatorname{Re} \times S c}\left[1+0.4 R e^{1 / 2} S c^{1 / 3}\right] \\
& +3 \phi+\left(\frac{S t-S^{*}}{S t-S^{*}+2 / 3}\right)^{3 / 2},
\end{aligned}
$$

where $D_{g}$ is the droplet diameter, $U_{t}$ the droplet velocity, $R e$ the Reynolds number, $S c$ the Schmidt number, $\phi$ the impaction parameter, $S t$ the Stokes number and $S^{*}$ the critical Stokes number. In this study, the droplet diameter has been arbitrarily fixed to $1 \mathrm{~mm}$. This efficiency vary with the aerosol size (Fig. 2a). Wet deposition is efficient for particles bigger than $2 . \times 10^{-7} \mathrm{~m}$.

Dry deposition is parametrized as a function of particle size and density, surface properties and micrometeorogical conditions near the surface (Nho et al., 2004). The expression of dry deposition velocity is

$v_{d}=\frac{1}{r_{a}+r_{b}}$,

where $r_{a}$ is the aerodynamic resistance and $r_{b}$ is the quasilaminar resistance and is the only term depending of aerosol size. These resistances are calculated following the parametrization of Nho et al. (2004). So, this velocity is proportional to the inverse of the quasi-laminar resistance. Figure $2 \mathrm{~b}$ represents the variations of the inverse of this resistance with particle size. Deposition on a surface is efficient for particles bigger than $1 \times$ $10^{-6} \mathrm{~m}$.

Sedimentation is calculated from Stokes law: particles fall because of their own weight. A correction coefficient is introduced to take into account the rarefaction of the air at high altitude:

$v_{s}=\frac{\rho_{p} D_{p}^{2} g C_{c}}{18 \mu_{\mathrm{air}}}$,

with

$C_{c}=1+\frac{2 \lambda}{D_{p}}\left[1.257+0.4 \exp \left(-0.55 D_{p} / \lambda\right)\right]$.

In these equations, $D_{p}$ is the particle diameter. Sedimentation velocity increases with size particles (Fig. 2c). 


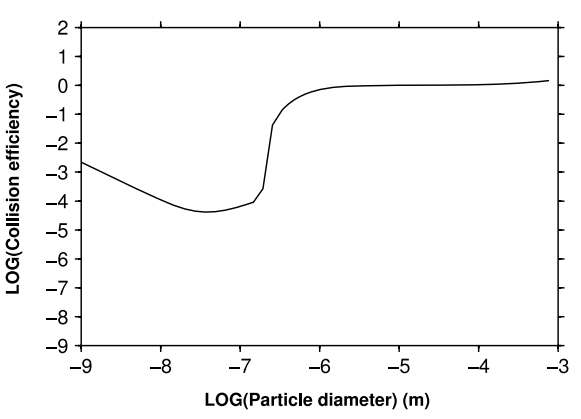

(a)

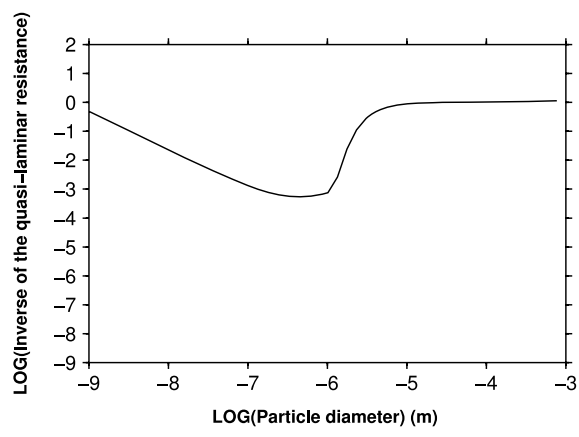

(b)

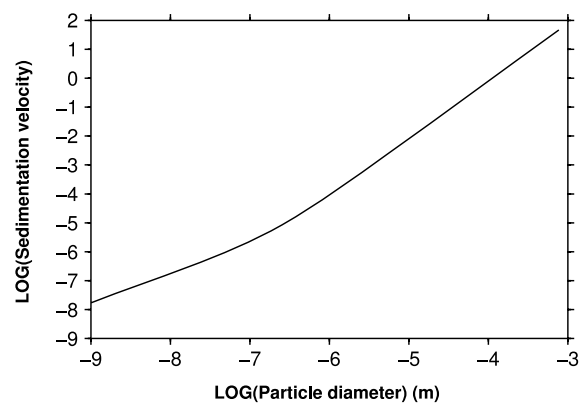

(c)

Fig. 2. Efficiency of the phenomena. a) Efficiency of collision between desert dust particles and rain droplets, as a function of the particle size. b) Inverse of the quasi-laminar resistance, as a function of the particle size. c) Sedimentation velocity as a function of the particle size.

In conclusion, we have to describe more precisely the concentrations of particles with diameters in the interval between $1 \times$ $10^{-6}$ and $5 \times 10^{-5} \mathrm{~m}$. In the following, MOCAGE uses a scheme with 20 bins and the bin-widths had been fixed considering the efficiencies of the sinks described above. Figure 3 represents the discretization in bins of the initial distribution and the Table 1 lists the mean, minimum and maximum diameters for all the bins.

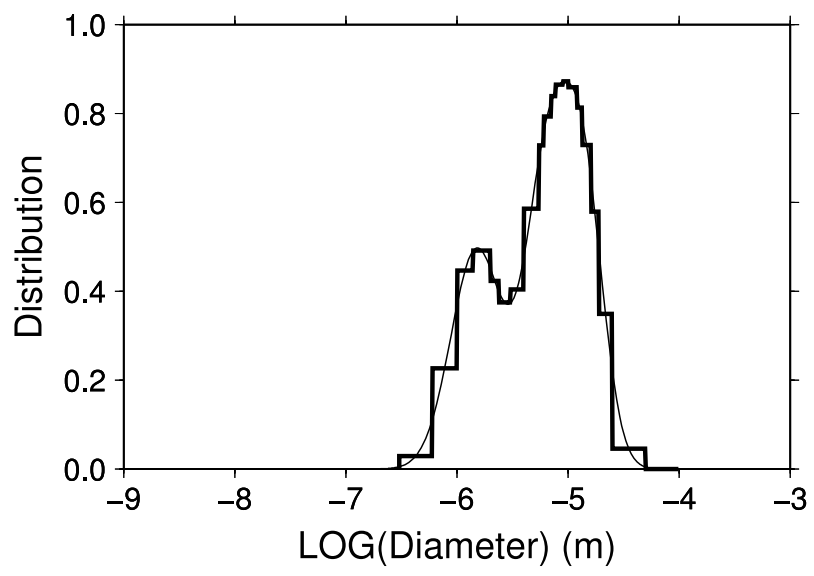

Fig. 3. Size bins for dust aerosol representation in MOCAGE.

\subsection{Optical properties}

Aerosol optical thickness is a parameter measured by satellite or by in situ sensors like radiometers in the AERONET network. The aerosol optical thickness $\tau$ is the dimensionless product of $b_{\text {ext }}$ (the extinction coefficent of the layer) and $z$ (the layer thickness). Considering that aerosols are spherical particles in MOCAGE, the extinction coefficient is related to the dimensionless extinction efficiency $Q_{\text {ext }}$ by

$b_{\mathrm{ext}}=\frac{\pi D_{p}^{2}}{4} N Q_{\mathrm{ext}}$,

where $N$ is the number concentration and $D_{p}$ the particle diameter. The dimensionless extinction efficiency is the rate between the extinction cross-section and the cross-sectional area of the particle. The aera of the extinction cross-section is the area of the shadow casted by the particle on the radiative energy. In MOCAGE, the extinction coefficient is calculated from the Mie and the complex refractive index $m$ of desert dust is

$m=n+i k=1.53-0.0078 i$,

following Chin et al. (2002). Aerosol optical thickness calculated in MOCAGE from desert dust concentrations, can be directly compared with measurements. 
Table 1. Mean, minimum and maximum diameters for each bin of the aerosol scheme used in our simulations

\begin{tabular}{lcccccccccc}
\hline Bin number & 1 & 2 & 3 & 4 & 5 & 6 & 7 & 8 & 9 & 10 \\
Mean $(\mu \mathrm{m})$ & 0.42 & 0.77 & 1.18 & 1.6 & 2.19 & 2.68 & 3.46 & 4.69 & 5.74 & 6.48 \\
Min $(\mu \mathrm{m})$ & 0.3 & 0.6 & 1 & 1.4 & 2 & 2.4 & 3 & 4 & 5.5 & 6 \\
Max $(\mu \mathrm{m})$ & 0.6 & 1 & 1.4 & 2 & 2.4 & 3 & 4 & 5.5 & 6 & 7 \\
Bin number & 11 & 12 & 13 & 14 & 15 & 16 & 17 & 18 & 19 & 20 \\
Mean $(\mu \mathrm{m})$ & 7.34 & 8.32 & 9.48 & 10.9 & 12.7 & 14.7 & 17.4 & 21.8 & 35.3 & 70.7 \\
$\operatorname{Min}(\mu \mathrm{m})$ & 7 & 7.7 & 9 & 10 & 12 & 13.5 & 16 & 19 & 25 & 50 \\
$\operatorname{Max}(\mu \mathrm{m})$ & 7.7 & 9 & 10 & 12 & 13.5 & 16 & 19 & 25 & 50 & 100 \\
\hline
\end{tabular}

\section{Study of a very long-range transport episode in November 2004}

We present results from a simulation of Saharan dusts emissions, transport and deposition for the period ranging from November 10 to December 1, 2004. The model starts from zero concentration on November 1. The spin-up period (from November 1 to November 10) is long enough to consider the whole dust emission of this episode. This period was characterized by very intense emissions of dust on November 14th over the Libyan territory. The maximum value of the emission flux computed by the model is $1.25 \times 10^{-5} \mathrm{~kg} \mathrm{~m}^{-2} \mathrm{~s}^{-1}$ and is simulated for November 14 at 1200 UTC over the North of Lybia.

After crossing the Eastern Mediterranean Sea, the dust cloud moves easterly across all Asia until November 21. Since the goal of this paper is to track the Saharan dust cloud, the possible emission of desert dust by Asian sources were not activated in the model. Thus, the cloud which goes through the Pacific is only composed of Saharan dust in our simulation. A significant fraction of the initial dust amount, which has not been deposited, reaches the West coast of the Northern America on November 27. Figure 4 represents the total column of dust calculated by MOCAGE on November 15 and November 27, 2004. On November 27, the total column of dust over Northern America is about $0.1 \mathrm{~g} \mathrm{~m}^{-2}$. This value is significant considering that the dust cloud has travelled over $24000 \mathrm{~km}$. Such very long-range transport of Saharan dust is seldom documented (McKendry et al., 2007). We use various data sources to evaluate the numerical simulation depending to their distance from the dust sources.

\subsection{Comparisons with observations close to the sources}

In the vicinity of dust sources, dust concentrations are important enough to affect visibility (Kaufman et al., 1997). Satellite data in visible channel are thus useful in determining the location of a dust cloud. The horizontal visibility is also affected by the presence of dust in the atmosphere, and this parameter is included in SYNOP operational meteorological messages. These two types of data can only be used near the source because the quantity of dust is such that dust constitutes the main part of the observed signal.
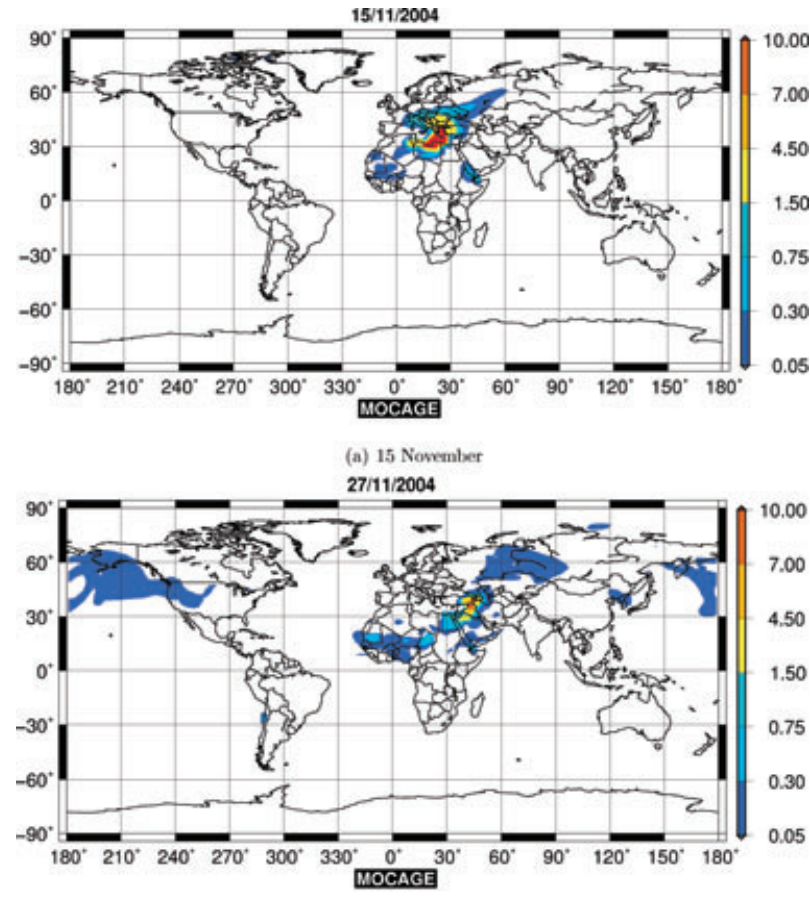

(b) 27 November

Fig. 4. MOCAGE dust column (in $\mathrm{g} / \mathrm{m}^{2}$ ) for two dates of the episode: 15 November (top) and 27 November (bottom).

Considering satellite observations, on November 14, the moderate resolution imaging spectroradiometer (MODIS) on NASA's Aqua satellite captured an image of rippling dust being swept northeastward across Libya and Tunisia (Fig. 5). The satellite image clearly shows the transport of dust over the Mediterranean Sea. MOCAGE results reveal a maximum of dust concentration on an area covering the Eastern Mediterranean Sea (from Libyan coasts to Turkey). This comparison strongly suggests that both the shape and the timing of the dust cloud is correctly reproduced by MOCAGE during the first hours following emission event.

Operational synoptic surface weather reports contain information about aerosols, either directly (eg. current and past weather) or indirectly (eg. horizontal visibility; WMO Table 


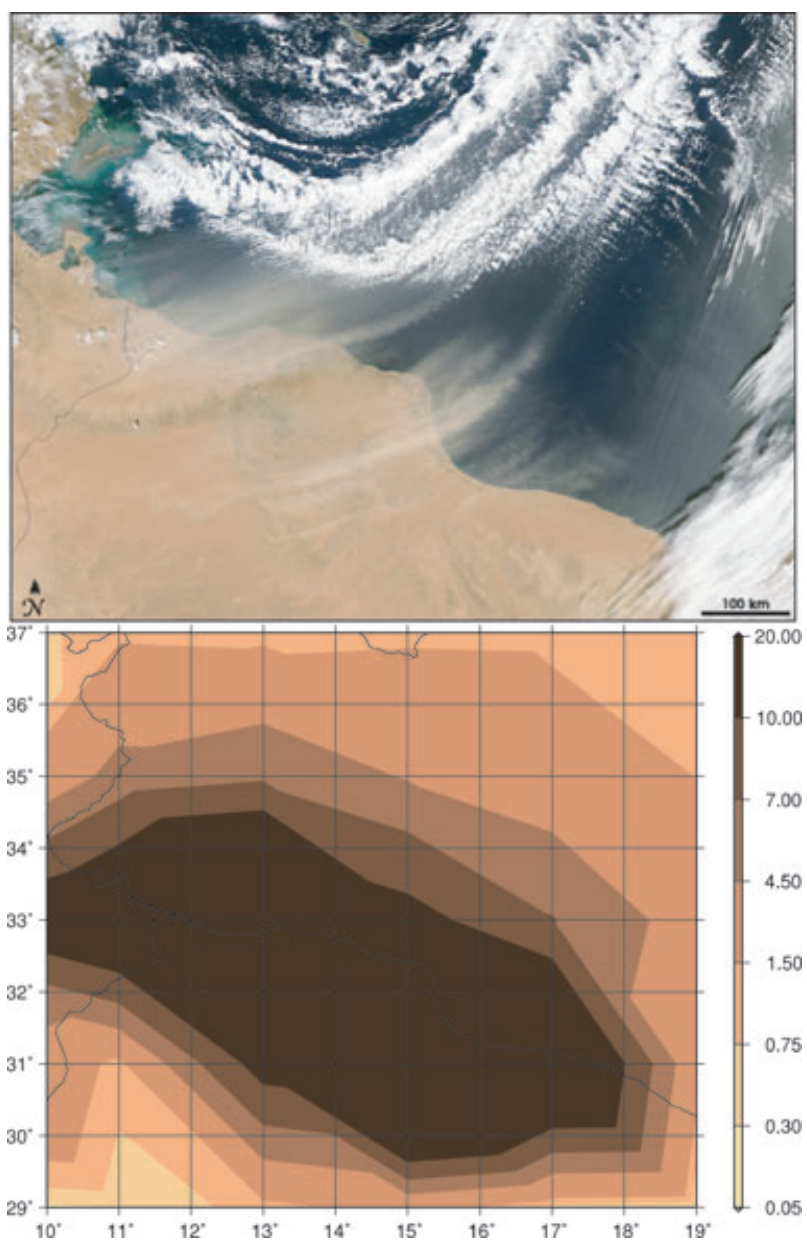

Fig. 5. Dust cloud blowing off Lybian coasts (November 14, 2004): MODIS satellite image compared to MOCAGE dust column (in $\mathrm{g} / \mathrm{m}^{2}$ ).

codes, 1995). Figure 6 shows the synoptic surface weather report for 16 November 2004 at 1200 UTC and the dust surface concentrations calculated by MOCAGE for the same date. The weather report indicates westerly winds and significant reduction of visibility over Israel and Jordan due to the presence of dusts (symbol $\infty$ and $S$ ). These observations matches well the position of the dust cloud simulated by MOCAGE. At this time, the simulated concentrations are between 400 and $3000 \mu \mathrm{g} \mathrm{m}^{-3}$; the highest concentrations being simulated over Cyprus. The weather reports of two stations located on this island indicate for the same date a significant reduction of visibility due to the presence of dust.

We select the visibility observations performed between 15 November and 19 November in the meteorological station of Damas in Syria to investigate more precisely the capability of the model to correctly reproduce the timing of the event. By default, when there is no visibility reduction, the value is set to $15000 \mathrm{~m}$ by observers for this parameter. Since MOCAGE does not directly compute the horizontal visibility, we used the aerosol optical thickness (AOT) as a proxy of visibility (AOT increases when visibility is reduced). The data are compared every $3 \mathrm{~h}$, which is the frequency at which the observations are available. Figure 7a shows the temporal evolution of the visibility as observed in Damas and that of the AOT as simulated by MOCAGE. The visibility is reduced on the 16 November between 0600 UTC and 1500 UTC, and on the 17 November at 0900 UTC. MOCAGE AOT suggests that a first dust cloud arrives over Damas on 15 November at 1800 UTC but that the major peak begins on 16 November at 0900 UTC. The model simulates an episode having a longer duration (by $6 \mathrm{~h}$ ) than that reported by the observations (in the simulations, the dust cloud remains over Damas until 17 November at 1500 UTC), which is not unexpected given that the horizontal resolution of the configuration of MOCAGE used here is $2^{\circ} \times 2^{\circ}$ (about $200 \mathrm{~km}$ ). At this stage, the dust particles have been transported over some $2000 \mathrm{~km}$ (from Lybia to Syria) and the results of MOCAGE are in line with the dusts observations available in that region.

\subsection{Comparisons with observations far from the sources}

Far from the sources, horizontal visibility cannot be used to check the simulations. Indeed, The total amount of dust is not sufficient to reduce visibility. Other types of observations have been considered: remote-sensing observations provides AOT measurements that are available all over the world. In situ measurements of aerosol concentrations are also available on few stations.

The aerosol robotic network (AERONET) programme is an inclusive federation of ground-based remote sensing aerosol networks (Holben et al., 1998). Data provides globally distributed observations of AOT. Two stations have been chosen on the path of the dust cloud: Dalanzadgad $\left(43^{\circ} \mathrm{E} ; 104^{\circ} \mathrm{N}\right)$ in Mongolia and Bratts Lake $\left(50^{\circ} \mathrm{N} ; 104^{\circ} \mathrm{W}\right)$ in Canada.

Figures $7 \mathrm{~b}$ and $\mathrm{c}$ shows the comparisons of AOT measured by the AERONET network and simulated by MOCAGE. Data are compared between 16 and 26 November 2004 for Dalanzadgad, between 21 November and 1 Decmber 2004 for Bratts Lake. These periods correspond to the dates at which MOCAGE simulates the transport of dust above these two stations. At Dalanzadgad, there is a time shift of $12 \mathrm{~h}$ on the date of the arrival of the dust cloud between observations and MOCAGE simulation: according to AERONET data, the cloud is observed at Dalanzadgad the 20 November at 0300 UTC whereas MOCAGE simulates it the 19 November at 1500 UTC. Despite this time shift, the maximum values of AOT between AERONET and MOCAGE are relatively consistent (0.048 for AERONET and 0.062 for MOCAGE). Considering Bratts Lake, the results are fair even if some observations are missing. Following MOCAGE simulations, the dust cloud reaches America on 25 November. The AOT measurements increase at the same time. Moreover, the maximum values are around 0.05 for the observations and 0.07 for the MOCAGE simulations. To confirm that the increase 
Fig. 6. Synoptic surface weather reports compared with MOCAGE dust surface concentrations in $\mu \mathrm{g} / \mathrm{m}^{3}$, November 16 , 2004 at 1200 UTC. Cyan symbols correspond to aerosol affected area. $S$ represents "widespread dust in suspension in the air, NOT raised by wind at the time of the observation" and $\infty$ "haze".

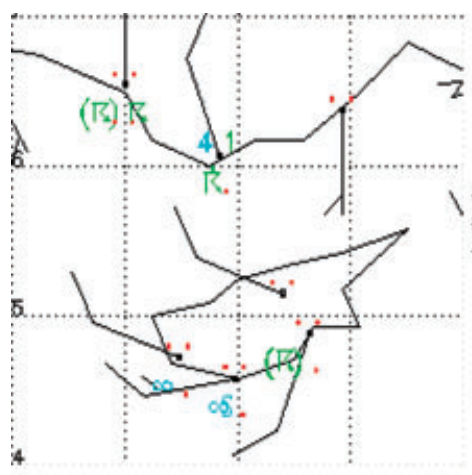

(a) Observations

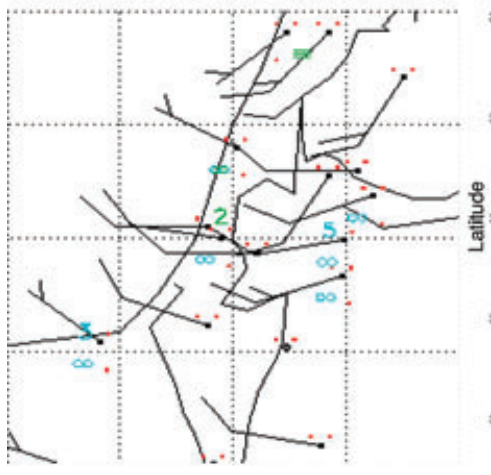

(b) Observations

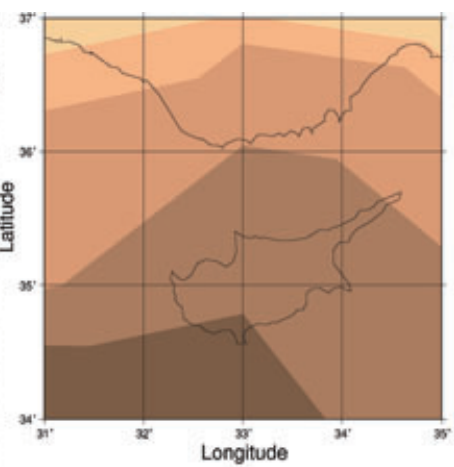

(c) MOCAGE

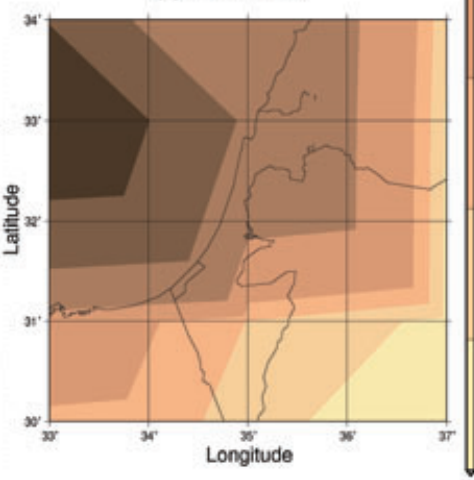

(d) MOCAGE
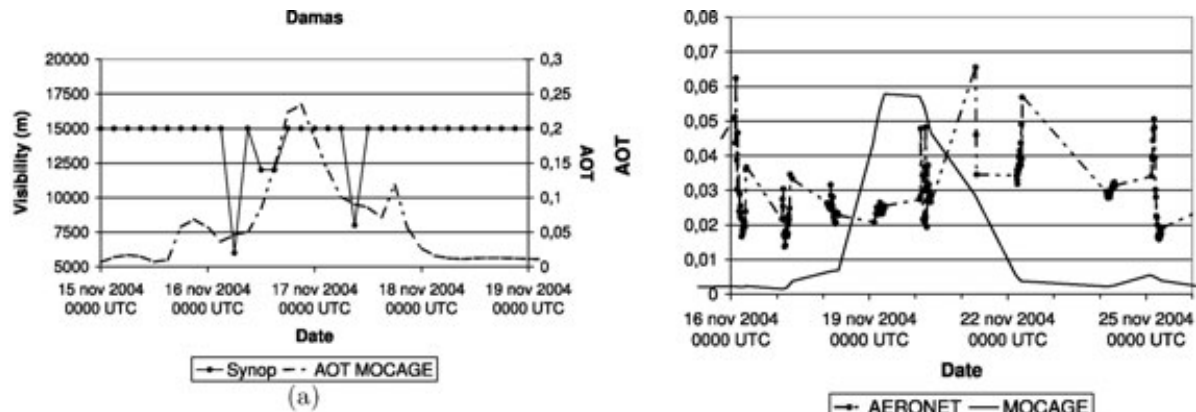

(b)
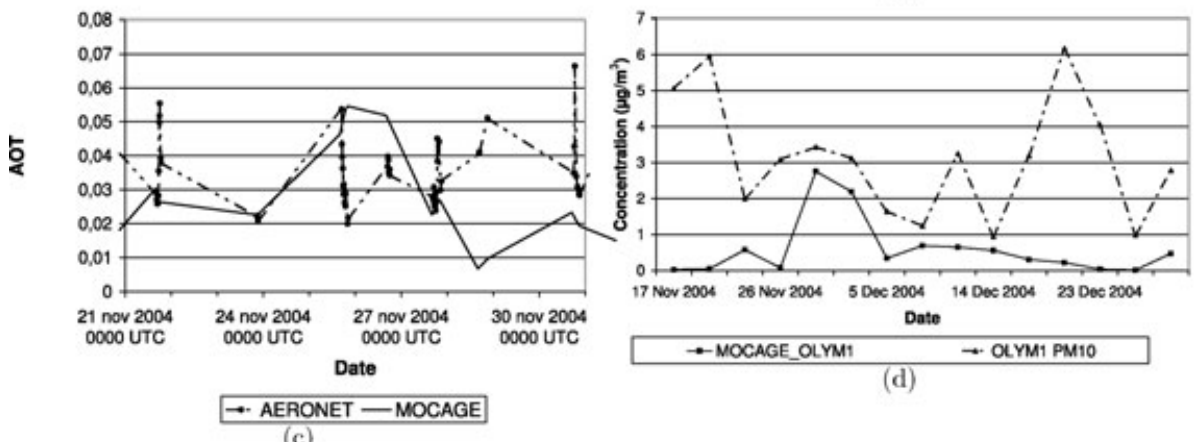

(d)

(c)

Fig. 7. Comparisons between observations and MOCAGE desert dusts concentrations. a) Visibility from Synop message in Damas and MOCAGE AOT results. b) AOT measured (dots) and calculated (line) at Dalanzadgad. c) AOT measured (dots) and calculated (line) at Bratts Lake.

d) Comparisons between IMPROVE PM10 observations (dotted line) and MOCAGE desert dusts concentrations (continuous line) at the station of Olympic. 
in AOT in Bratts Lake is connected with a long-range dust transport event, we also used in situ data. The Interagency Monitoring of Protected Visual Environments (IMPROVE) monitoring network consists of aerosol, light scatter, light extinction and scene samplers in a number of National Parks and Wilderness areas (Joseph et al., 1987). The IMPROVE programme includes the measurement of the composition and concentration of tracers allowing to identify emission sources. The standard IMPROVE instrument has four sampling modules, one collects PM10 particles $(0-10 \mu \mathrm{m})$. This parameter is not directly the quantity of desert dust but dusts are a large fraction of it (following Malm et al., 2007). We have considered the station of Olympic, Washington $\left(48^{\circ} \mathrm{N} ; 123^{\circ} \mathrm{W}\right)$, which is relatively close to Bratts Lake.

Figure $7 \mathrm{~d}$ shows the comparisons between the PM10 in situ observations and MOCAGE simulations during the last days of November and the first days of december 2004 (from 17 to 23 November 2004). Observed PM10 concentrations (in $\mu \mathrm{g} \mathrm{m}^{-3}$ ) and dust concentrations (in the same unit) simulated by MOCAGE are compared. Considering Olympic, an increase of PM10 occurs the 29 November, in phase with the maximum concentration of desert dust simulated by MOCAGE.

Nevertheless, we can wonder if the particles reaching Olympic are really coming from Pacific Ocean and rather not from local or continental sources of PM10. The occurrences of wind directions during this period (Fig. 8) show that the main wind direction is Southwest, which is the direction for winds coming from the Pacific Ocean at the Olympic station. Thus, we can assume that most of the particles observed at this station are probably not coming from local sources or from American sources of dusts but are probably particles having travelled over the Pacific Ocean.

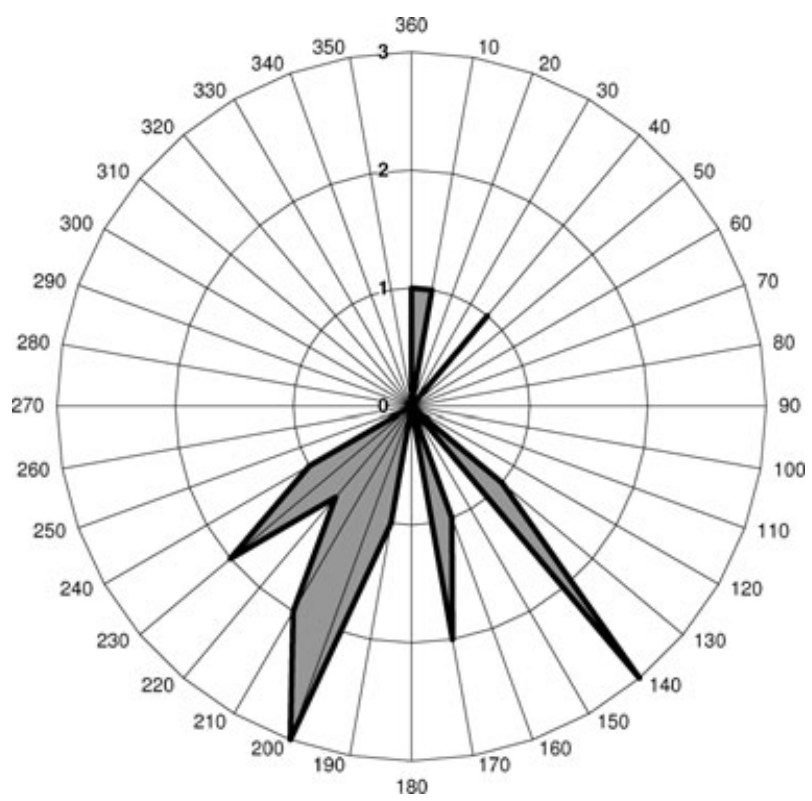

Fig. 8. Occurrences of wind directions between November 24, 2004 and November 30, 2004 at the station of Olympic.

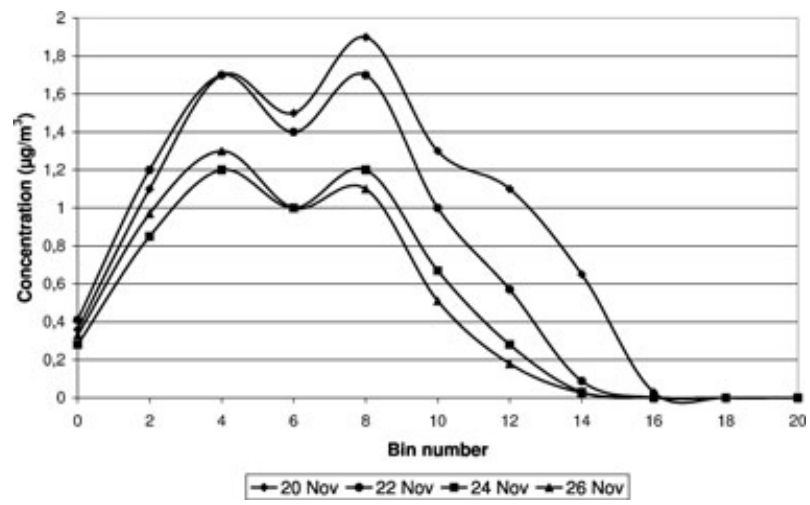

Fig. 9. Evolution of the dust size distribution during the transport between Africa and America for the November 2004 case for four different dates.

We provide now some insight on the evolution of the dust particles granulometry during this very long-range transport. During the transport, depositions (wet, dry and by sedimentation) have different impacts on dust concentrations following their diameters. The evolution of the concentration of each bin has been studied during the transport of dust from Africa to America. Figure 9 represents the evolution of these concentrations during November. The three log-normal modes of the initial distribution are visible at the first date (20 November 2004). During the transport, the deposition is more efficient on big particles. This phenomenon is visible on the evolution of the third mode of the distribution. Considering the concentrations of the last date (26 November 2004), the distribution has only two modes, the biggest particles have been progressively eliminated by the different sinks. This indicates very different lifetimes across the spectrum of the dust size distributions, as precised for instance in (Tegen and Fung, 1994).

This leads to a remark: a log-normal approach would be a real shortcoming for such long-range transport episodes, as modes (and specially the coarse ones) are gradually departing from the initial gaussian distributions. This is also of importance regarding the initial total dust mass deposited far from the source zone.

\section{Study of a trans-Atlantic episode in May 2007}

In May 2007, the air quality network Madininair of Martinique Island $\left(14^{\circ} \mathrm{N} ; 61^{\circ} \mathrm{W}\right)$ in the Caribbean Sea recorded the highest value of PM10 observed since the begining of their operations in 2000. These high particulate concentrations were suspected to result from an intense Saharan dust transport. Such cases of transatlantic transport of dusts have already been reported (Mahowald et al., 2002). Some campaigns have studied similar cases like Puerto RIco Dust Experiment (PRIDE; Reid et al., 2003; Colarco et al., 2003a,b) or Saharan Dust Experiment (SHADE; Formenti et al., 2003; Myhre et al., 2003). 
For May 2007, the simulation starts from zero concentration on 1 May 2007. As in the November case, the spin-up time lasts around one week. MOCAGE simulates strong dust emissions in Mauritania. The maximum flux is about $2.8 \times 10^{-4} \mathrm{~kg} \mathrm{~m}^{-2} \mathrm{~s}^{-1}$. At the beginning of the episode, the area of maximum concentrations (more than $150 \mu \mathrm{g} \mathrm{m}^{-3}$ ) is located between the West African coasts and the Cape Verde Islands. The vertical extension is about $2 \mathrm{~km}$ (until $800 \mathrm{hPa}$ ). This cloud moves westward across the Atlantic Ocean and reach Martinique on 15 May 2007. Despite of sedimentation, dry and wet deposition, the concentrations simulated by MOCAGE in Martinique remain very high (between 80 and $150 \mu \mathrm{g} \mathrm{m}^{-3}$ on May 15). Zonal crosssections show that the vertical dust transport occurs only in the two first kilometres of the atmosphere (not presented here).

\subsection{Comparisons with observations close to the sources}

Figure 10 compares MODIS image and the column of dust simulated by MOCAGE (in $\mathrm{g} \mathrm{m}^{-2}$ ) at the same date (9 May 2007). On the MODIS image, we note that a dust plume with a width of several hundred kilometres blew off the west coast of Africa on 9 May 2007. This image shows the dust plume fading out approximately $500 \mathrm{~km}$ west of the coast. The plume is thickest in the south, near Cape Verde Islands, although a plum of dust stretches out toward the Canary Islands in the north. Nevertheless, the area of maximum concentrations is quite well captured by MOCAGE, located between the west coast of Africa and Cape Verde Islands.

As for the November 2004 case, we have examined the synoptic surface weather reports in order to estimate the consistency between MOCAGE simulations and the observations. Figure 11 shows the synoptic surface weather report on the west African coast and Cape Verde Islands as well as the dust surface concentration simulated by MOCAGE for the same date ( 9 May at 1200 UTC).

In Mauritania and Senegal, all weather reports indicate that the horizontal visibility is reduced (from 2 to $4 \mathrm{~km}$ ) because of dust. Messages from Morocco also point out reduced visibilities but less intense than in the two countries mentionned above. These observations confirm that the location of the dust cloud in the MOCAGE simulation is correct. In Cape Verde Islands, horizontal visibility is reduced to $2.8 \mathrm{~km}$ and the symbol associated means 'widespread dust in suspension in the air'. At this date, the area of maximum concentration is located near Cape Verde Islands in the MOCAGE simulation suggesting that the shape and extension of the cloud are realistic.

Figure 12 shows the evolution of the AOT measured by AERONET over Cape Verde Islands and simulated by MOCAGE. The absolute maximum observed is around 2.3 (9 May at 1741 UTC). During the following days, peaks of AOT are observed. In particular, AOT reaches 1.5 the day after the first peak. This second maximum is caused by another strong dust emission in West Africa. MOCAGE simulation represents

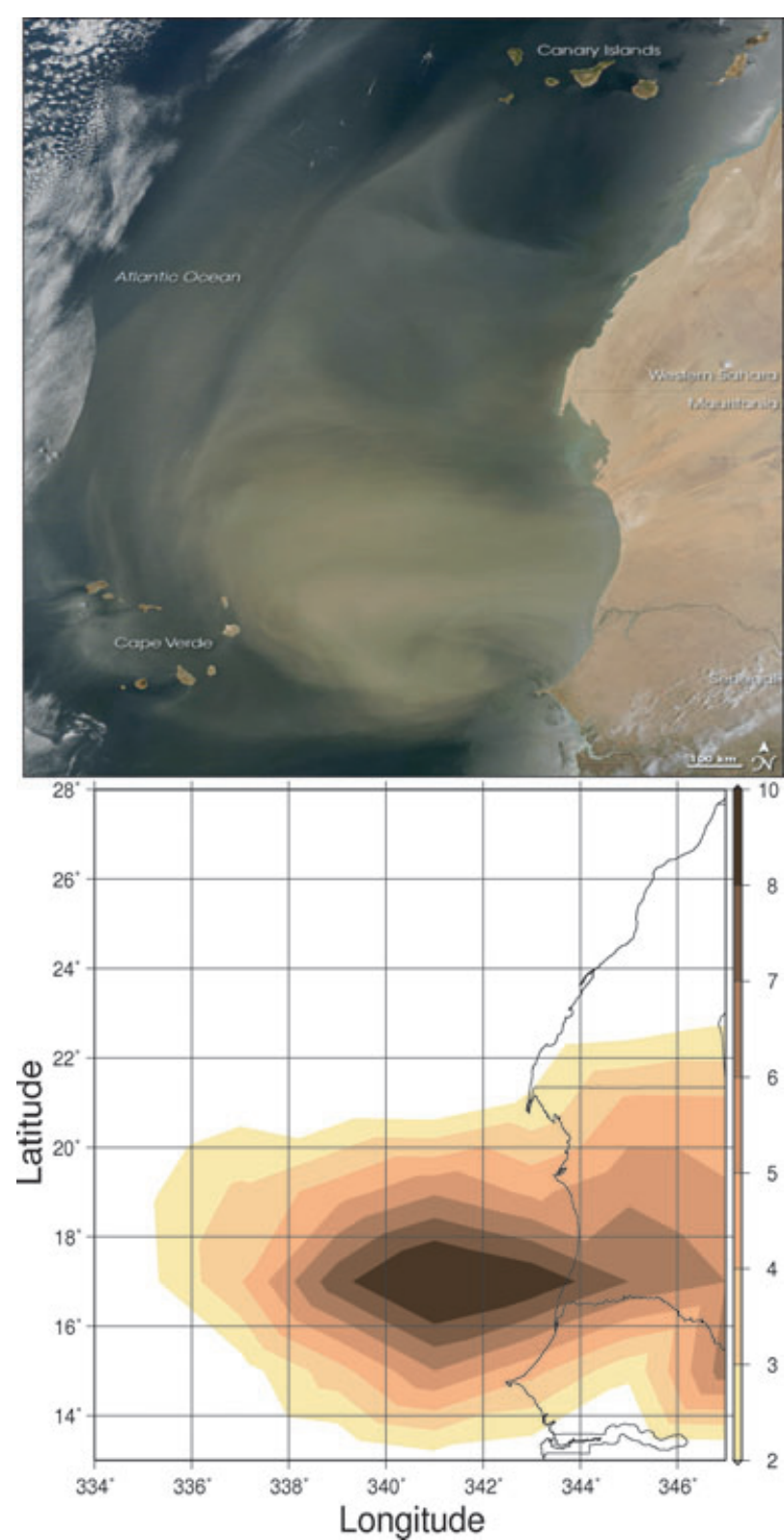

Fig. 10. Dust cloud blowing off African coasts (May 5, 2007). MODIS image and MOCAGE dust column on $\mathrm{g} / \mathrm{m}^{2}$.

only one maximum during that period. This maximum value is 1.3 (9 May at 1200 UTC). This peak is underestimated by the model and occurs about $5 \mathrm{~h}$ earlier compared to the observations. The underestimation could be explained by the horizontal resolution of $2^{\circ}$ used here. Such a resolution smoothes the dust concentrations and consequently, the AOT simulated. Still, the agreement is quite nice. Considering the secondary peaks that are not simulated by MOCAGE, it is caused by an underestimation of the dust emission fluxes over Africa the days following the first emission. The AOT observations over Cape Verde show 


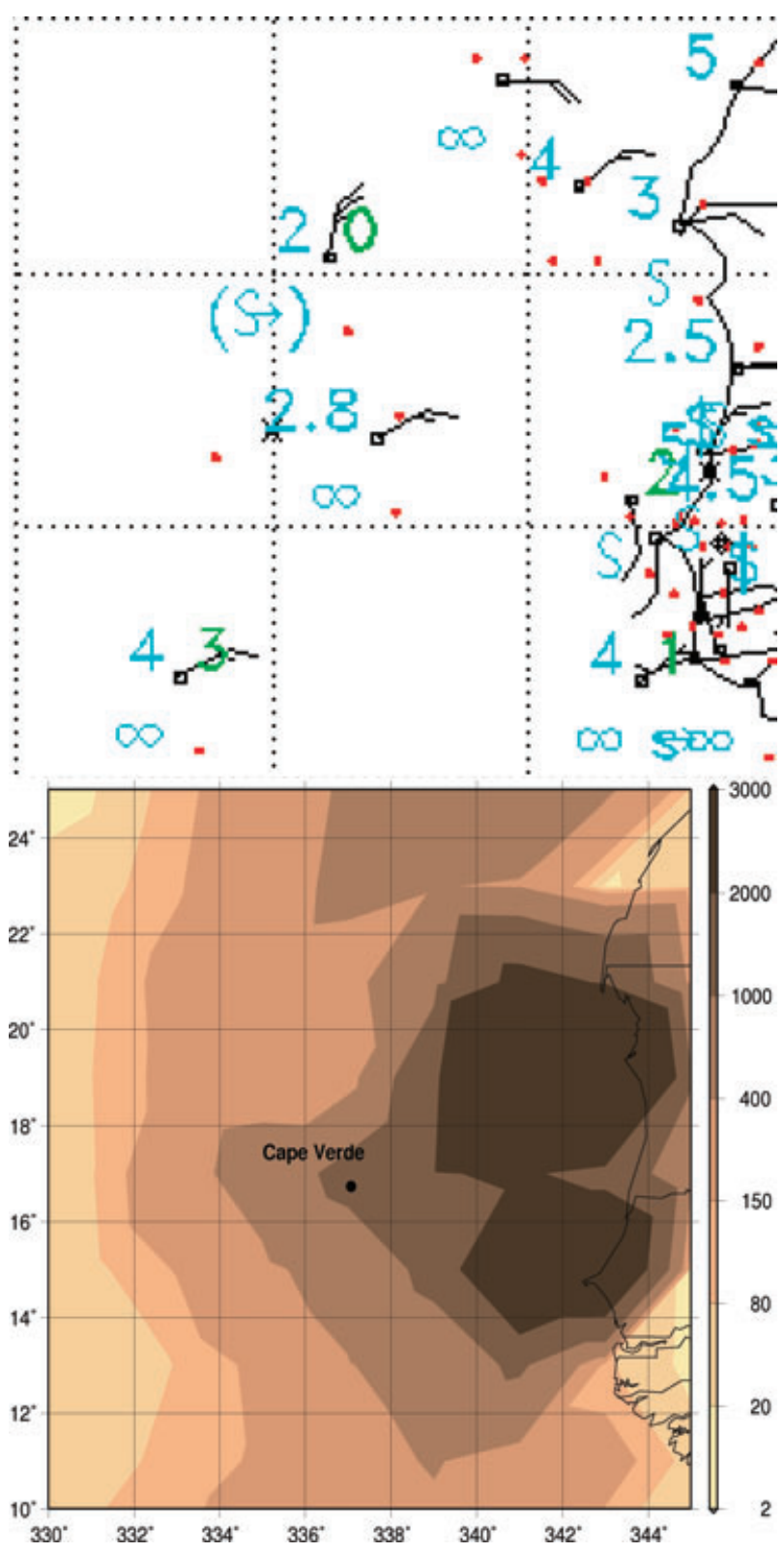

Fig. 11. Synoptic surface weather reports compared with MOCAGE dust surface concentration in $\mu \mathrm{g} / \mathrm{m}^{3}$, May 9, 2004 at 1200 UTC. Cyan symbols correspond to aerosol affected area. S represents "widespread dust in suspension in the air, NOT raised by wind at the time of the observation" and $\infty$ "haze".

that emissions happened the days following the first emissions. But, MOCAGE dust emission fluxes are not important enough in Africa between the 9 and 12 May 2007. This underestimation of the emission flux is responsible of the bad representation of the secondary peaks observed in AOT measurements over Cape Verde.

MOCAGE simulation indicates that the dusts emitted in West Africa are transported over the Atlantic Ocean along the 10th parallel. Figure 13 compares the GOES-E (a geostationary satellite having its operationnal position is $75^{\circ} \mathrm{W}$ ) colour-composed image produced by Météo-France (Bellec and Le Gléau, 1992) and the dust column represented by MOCAGE at the same date: 16 May 2007 at 1500 UTC. The colour-composed image is a combination of infrared and visible channels, the clouds are colored with different shades. On this image, the dust cloud has a light brown color. This image is the basis of a qualitative comparison of MOCAGE results with the reality. On the satellite observation, the dust cloud spreads from the African coasts to the Caribbean Sea. MOCAGE results match very well with this position. The dust column simulated by the model is placed on the same area. High values (higher than $0.5 \mathrm{~g} \mathrm{~m}^{-2}$ ) are situated over West Africa (specially over Guinea), spread along the 10th parallel and reach South American coasts. This comparison confirms that the trajectory and timing of the dust cloud are correct in MOCAGE simulation.

\subsection{Comparisons with observations far from the sources}

The synoptic surface weather report for Caribbean islands points out the presence of dusts on 14 May at 1800 UTC. All the stations of the area report 'haze' (symbol $\infty$ ), on the south of the zone, some reports talk about 'widespread dust in suspension in the air, NOT raised by wind at the time of the observation' (symbol $S$ ) and in Martinique, the horizontal visibility is reduced to $2 \mathrm{~km}$ because of dusts. The dust column simulated by MOCAGE suggests that high dust concentrations reach Martinique at the same date (Fig. 14). The position of the dust cloud represented by the model seems to be less stretched out on the north of the area.

In Martinique, five stations are measuring operationaly PM10 concentrations every day since 2000 . They are operated by Madininair, the local air quality network. A warning has been published by them on 15 May, the PM10 concentration reaching a maximum value of $155 \mu \mathrm{g} \mathrm{m}^{-3}$. Such a particulate concentration had never been measured on this island. Again, it should be underlined that PM10 includes all types of aerosols (black carbon, sea salts...) and not only desert dusts. Figure 15 shows the evolution of PM10 measured at the Lamentin station and the desert dusts concentration simulated by MOCAGE. The first day (May 13, 2007), PM10 is about $50 \mu \mathrm{g} \mathrm{m}^{-3}$ but the Saharan dust cloud has not reached Martinique yet. This concentration can be considered as representative of typical levels of PM10 at this monitoring site in the absence of any specific event. MOCAGE, in the configuration used here, does not account for other sources than dust and these typical levels of particulate matter cannot be represented in the simulation. Thus, to compare MOCAGE simulation, we have to remove this background concentration; only the values in excess of $50 \mu \mathrm{g} \mathrm{m}^{-3}$ are thus expected to mainly account for dusts.

The dust concentration calculated by MOCAGE rises from May 13 at 1200 UTC and reaches a maximum value of 
Fig. 12. Comparison between AOT observations (dots) and MOCAGE AOT at Capo Verde, from May 1 to May 20, 2007.

Fig. 13. Multispectral colour-composite image (Météo-France) compared with MOCAGE dust total column in $\mathrm{g} / \mathrm{m}^{2}$, May 16, 20071500 UTC.

\section{Cape Verde}
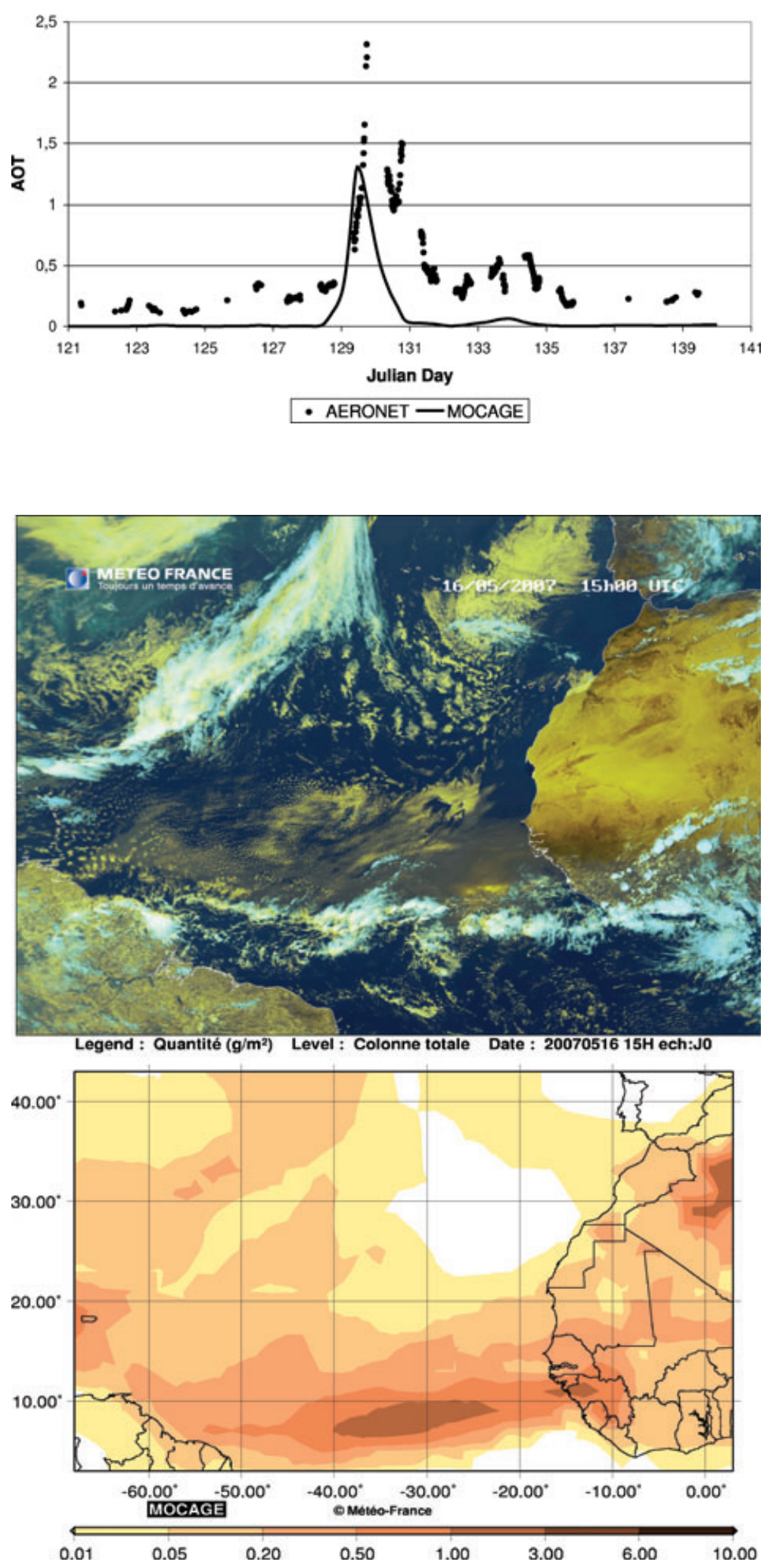

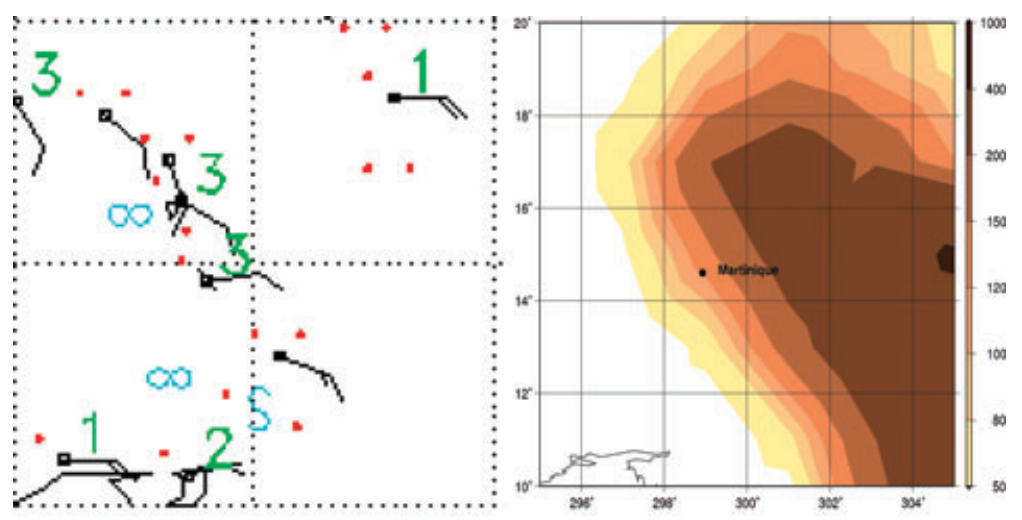

(a) Observations

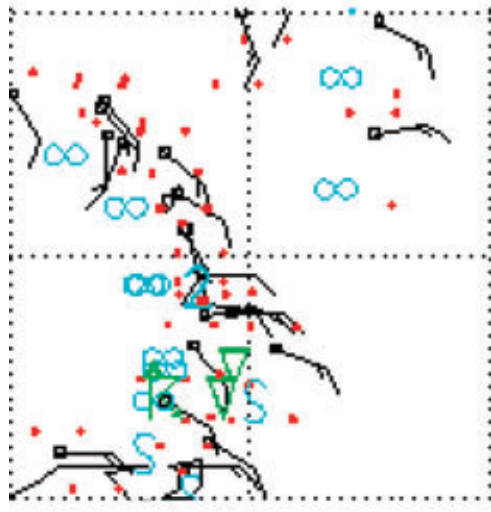

(b) Observations (c) MOCAGE

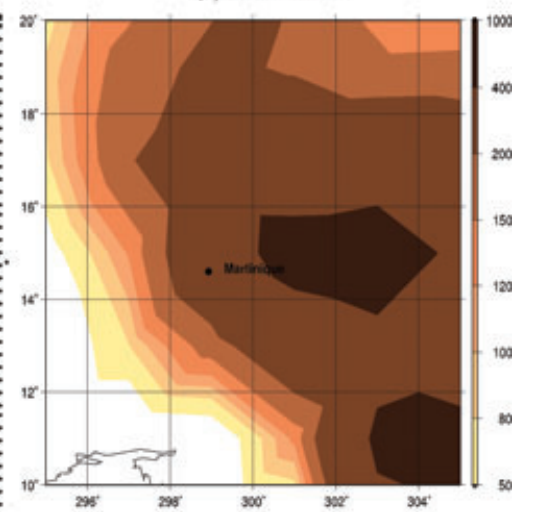

(d) MOCAGE
Fig. 14. Synoptic surface weather reports compared with MOCAGE dust surface concentration in $\mu \mathrm{g} / \mathrm{m}^{3}$, May 14, 2007 at 0600 UTC and 1800 UTC. Cyan symbols correspond to aerosol affected area. S represents "widespread dust in suspension in the air, NOT raised by wind at the time of the observation" and $\infty$ "haze".

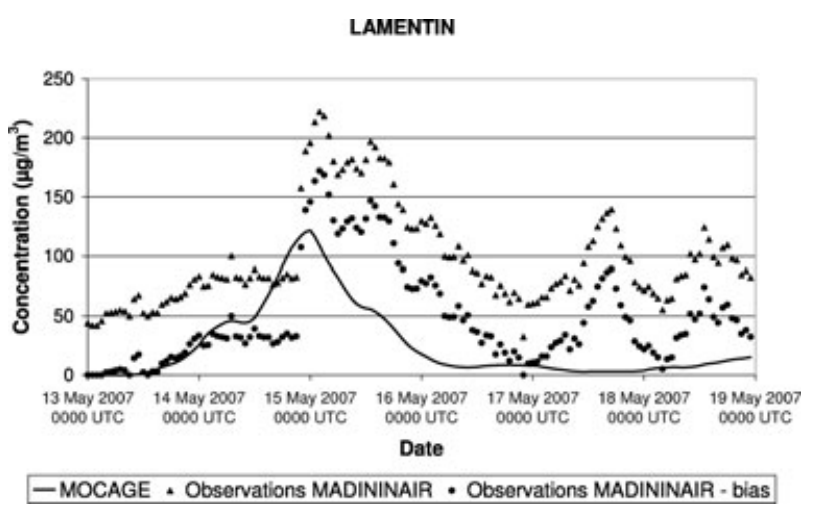

Fig. 15. Comparison between PM10 observations (triangles) and MOCAGE concentrations at Lamentin, from May 13 to May 20, 2007. The dots correspond to observations minus $50 \mu \mathrm{g} / \mathrm{m}^{3}$, corresponding to the background PM10 concentrations at this time in Lamentin.

$121.8 \mu \mathrm{g} \mathrm{m}^{-3}$ (15 May 2007, 0000 UTC). During the two first days of simulations, observations and modelled concentrations are in good agreement. MOCAGE represents the arrival of the dust cloud by a gradual increase of the concentration. The maximum value is simulated a few hours earlier than in the observations, but the maximum is in the correct range.

During the following days, MOCAGE evacuates the dust cloud more quickly than observed. The concentrations are lower than $10 \mu \mathrm{g} \mathrm{m}^{-3}$ from 16 May at $0400 \mathrm{UTC}$ in the simulations and from 16 May at 2200 UTC in the observations. Moreover, two maxima are observed in the PM10 data (17 May at 1700 UTC and 18 May at 1300 UTC). These high concentrations are not represented in the model, probably because of an underestimation of secondary Saharan dust emissions during the days after the major one as previously underlined by the comparison of measured and simulated AOT over Cape Verde Islands.

During this episode of Saharan dust transported to the Caribbean islands, the simulation of aerosol concentrations by MOCAGE is satisfying. Indeed, on a qualitative way, comparisons with horizontal visibility and satellite image have shown that the location and time of arrival of the dust cloud have been well simulated by the model. On a quantitative way, the comparison of dust concentrations with PM10 measurements has shown that the results of MOCAGE are consistent with the fraction of observed PM10 not attributable to local air pollution sources, several thousands of kilometres away from the emissions sources. The study of the AOT measurements over Cape Verde and the PM10 measurements in Martinique Island have shown that MOCAGE correctly simulates the first peak of dust concentrations but do not simulate the following peaks due to an underestimation of the dust emission flux.

As in the case of November 2004, the evolution of the dust size distribution have been studied during the transport from Africa 


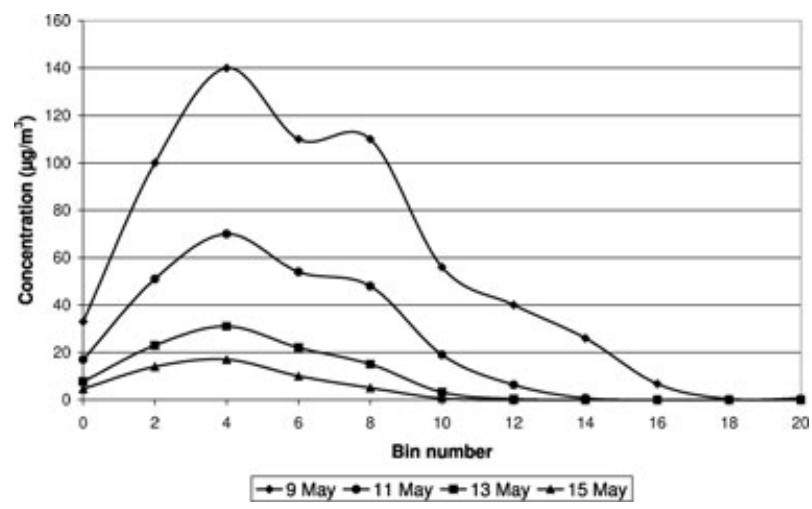

Fig. 16. Evolution of the dust size distribution during the transport between Africa and Caribbean Islands for the May 2007 case.

to Caribbean Islands. Figure 16 represents the evolution of these concentrations during May. On 9 May, the cloud is located near the sources and the dust distribution is similar to the emission size distribution - three log-normal modes. The following days, depositions eliminate dust from the atmosphere and the size distribution shows that the big particles are eliminated faster than the little. Thus, when the dust cloud reach Martinique Island (May 15), the third mode has disappeared and the concentrations of particles bigger than $6.5 \mu \mathrm{m}$ (bin number 10) is negligible. The evolution of the aerosol size distribution follows the same scheme than in the case of November 2004 - the third mode is eliminated faster and each mode is distorted because of the variable treatment of sinks following particle sizes.

\section{Conclusions}

The study of two very long-range transport episodes of dust transport has been used to evaluate our model simulations. In turn, the model simulations have allowed to better understand the chronology of the event and to make the link between different types of observations to build a consistent picture. The comparisons with available data (satellite observations, horizontal visibility, PM10 measurements) have shown that the representation of Saharan dusts in MOCAGE is realistic in two very different cases: the transport of dusts from Africa to Northern America across Asia and the Pacific, and the transport of an intense outbreak of desert dusts from West Africa to Carribean Islands. During both events, the simulations of the dust cloud path were realistic and the timing of the arrival of dust on the different sites where observations are available was in general anticipated by only a few hours. In this study, horizontal visibility in SYNOP messages has been used to contribute to the evaluation of our numerical simulations. Although reduction of visibility can result from a number of reasons (dust, but also other aerosols or moisture) and is thus only semi-quantitative, the use of this type of observations in synergy with other sources of data available operationaly (PM10 and AOT measurements) provide strong constraints for routine dust forecast models evaluation. The MOCAGE model, evaluated in this study, is providing daily dust forecasts on the French national platform Prev'Air (Honoré et al., 2008).

\section{Acknowledgments}

The authors would like to thank MADININAIR for the PM measurements in Martinique Island, CMS Lannion for the colourcomposite satellite image, AERONET for AOT measurements and IMPROVE for the aerosol concentrations measurements. We thank Brent Holben, Didier Tanré and Bruce McArthur for theirs effort in establishing and maintaining Dalanzadgad, Cape Verde and Bratts Lake sites.

\section{Appendix A}

Internet Sites

$\begin{array}{ll}\text { AERONET } & \text { http://aeronet.gsfc.nasa.gov/index.html } \\ \text { PREV'AIR } & \text { http://www.prevair.org/ } \\ \text { SDSWS } & \mathrm{http} / / / \text { salam.upc.es/wmo/ } \\ \text { IMPROVE } & \mathrm{http}: / / \text { vista.cira.colostate.edu/improve/ } \\ \text { MADININAIR } & \mathrm{http}: / / \text { www.madininair.asso.fr/ } \\ \text { MODIS } & \mathrm{http} / / / \text { rapidfire.sci.gsfc.nasa.gov/ } \\ \text { NRL } & \mathrm{http} / / / \text { www.nrlmry.navy.mil/aerosol/ }\end{array}$

\section{References}

Ackermann, I. J., Hass, H., Memmesheimer, M., Ebel, A., Binkowski, F. S. and co-authors. 1998. Modal aerosol dynamics model for Europe: development and first applications. Atmos. Environ. 32, 29812999.

Bechtold, P., Bazile, E., Guichard, F., Mascart, P. and Richard, E. 2001. A mass flux convection scheme for regional and global models. $Q$. J. R. Meteorol. Soc. 127, 869-886.

Bellec, B. and Le Gléau, H. 1992. The multispectral colour-composite technique: an improved method to display meteorological satellite imagery. Int. J. of Remote Sens. 13, 1981-1998.

Bergametti, G., Remoudaki, E., Losno, R., Steiner, E., Chatenet, B. and co-authors. 1992. Sources, transport and deposition of atmospheric phosphorus over the northwestern Mediterranean. J. Atmos. Chem. 14, 501-513.

Binkowski, F. S. and Shankar, U. 1995. The regional particulate matter model, 1: model description and preliminary results. J. Geophys. Res. 100, 26 191-26209.

Bousserez, N., Attié, J.-L., Peuch, V.-H., Michou, M., Pfister, G. and co-authors. 2007. Evaluation of MOCAGE chemistry and transport model during the ICARTT/ITOP experiment. J. Geophys. Res., 112, D120S42, doi:10.1029/2006JD007595.

Callot, Y., Marticorena, B. and Bergametti, G. 1990. Geomorphological approach for modelling the surface features over arid environments in a model of dut emissions: application to the Sahara desert. Geodinamica Acta 13, 245-270.

Chaboureau, J.-P., Tulet, P. and Mari, C. 2007. Diurnal cycle of dust and cirrus over West Africa as seen from Meteosat second genera- 
tion satellite and a regional forecast model. Geophys. Res. Lett. 34, L02822, doi:10.1029/2006GL027771.

Chaumerliac, N. 1984. Evaluation des dépÀts humides des polluants atmosphériques dans un modÀ le météorologique À méso-échelle, 1: Captation dynamique. Note IOPG, No.74.

Chin, M., Ginoux, P., Kinne, S., Torres, O., Holben, B. N. and coauthors. 2002. Tropospheric aerosol optical thickness from the GOCART model and comparisons with satellite and sun photometer measurements. J. Atmos. Sci. 59, 461-483.

Colarco, P. R., Toon, O. B. and Holben, B. N. 2003a. Saharan dust transport to the Caribbean during PRIDE, 1: influence of dust sources and removal mechanisms on the timing and magnitude of downwind aerosol optical depth events from simulations of in situ and remote sensing observations. J. Geophys. Res. 108, 8589, doi:10.1029/2002JD002658.

Colarco, P. R., Toon, O. B., Reid, J. S., Livingston, J. M., Russell, P. B. and co-authors. 2003b. Saharan dust transport to the Caribbean during PRIDE, 2: transport, vertical profiles, and deposition in simulations of in situ and remote sensing observations. J. Geophys. Res. 108, 8590, doi:10.1029/2002JD002659.

Dufour, A., Amodei, M., Ancellet, G. and Peuch, V.-H. 2004. Observed and modelled "chemical weather" during ESCOMPTE. Atmos. Res. 74, 161-189.

Fécan, F., Marticorena, B. and Bergametti, G. 1999. Parameterization of the increase of the aeolian erosion threshold wind friction due to soil moisture for semi-arid areas. Annales Geophysicae 17, 149-157.

Formenti, P., Elbert, W., Maenhaut, W., Haywood, J. and Andreae, M. O. 2003. Chemical composition of mineral dust aerosol during the Saharan Dust Experiment (SHADE) airborne campaign in the Cape Verde region, September 2000. J. Geophys. Res. 108, 8576, doi:10.1029/2002JD002648.

Ginoux, P., Prospero, J. M., Torres, O. and Chin, M. 2004. Long-term simulation of global dust distribution with the GOCART model: correlation with North Atlantic Oscillation. Environ Model. Software 19, 113-128.

Gong, S. L., Zhang, X. Y., Zhao, T. L., Zhang, X. B., Barrie, L. A. and co-authors. 2006. A Simulated climatology of Asian dust aerosol, and its trans-Pacific transport, part II: interannual variability and climate connections. J. Clim. 19, 104-122.

Holben, B. N., Eck, T. F., Slutsker, I., Tanre, D., Buis, J. P. and co-authors. 1998. AERONET-A Federated Instrument Network and Data Archive for aerosol characterization. Remote Sens. Env. 66, 1-16.

Honoré, C., Rouil, L., Vautard, R., Beekmann, M., Bessagnet, B. and co-authors. Predictability of European air quality: assessment of 3 years of operational forecasts and analyses by the PREV'AIR system. J. Geophys. Res., doi:10.1029/2007JD008761.

Jacobson, M. Z. 1997. Development and application of a new air pollution modeling system, part II: aerosol module structure and design. Atmos. Environ. 31, 131-144.

Jickells, T. D., An, Z. S., Andersen, K. K., Baker, A. R., Bergametti, G., and co-authors. 2005. Global iron connections: between desert dust, ocean biogeochemistry and climate. Science, 308, 67-71.

Joseph, D., Metza, B. J., Malm, W. C. and Pitchford, M. L. 1987. Plans for IMPROVE: a federal program to monitor visibility in class I areas. In: Visibility Protection: Research and Policy Aspects (ed. P. J. Bhardwaja). Air Pollution Control Association, Pittsburgh, Russia.

Josse, B., Simon, P. and Peuch, V.-H. 2004. Rn-222 global simulations with the multiscale CTM MOCAGE. Tellus 56B, 339-356.
Kaufman, Y. J., Tanré, D., Gordon, H. R., Nakajima, T., Lenoble, J. and co-authors. 1997. Passive remote sensing of tropospheric aerosol and atmospheric correction for the aerosol effect. J. Geophys. Res. 102, 16815-16830.

Langner, J. and Rodhe, H. 1991. A global three-dimensional model of the tropospheric sulfur cycle. J. of Atmos. Chem. 13, 225-263.

Laurent, B., Marticorena, B., Bergametti, G., Chazette, P., Maignan, F. and co-authors. 2005. Simulation of the mineral dust emission frequencies from desert areas of China and Mongolia using an aerodynamic roughness length map derived from the POLDER/ADEOS 1 surface products. J. Geophys. Res. 110, D18S04, doi:10.1029/2004JD005013.

Laurent, B., Marticorena, B., Bergametti, G. and Mei, F. 2006. Modeling mineral dust emissions from Chinese and Mongolian deserts. Glob. Planet. Changes 52, 121-141.

Louis, J. F. 1979. A parametric model of vertical eddy fluxes in the atmosphere. Bound.-Layer Meteorol. 17, 182-202.

Lunt, D. J. and Valdes, P. J. 2002. The modern dust cycle: comparison of model results with observations and study of sensitivities. J. Geophys. Res. 107, 4669, doi:10.1029/2002JD002316.

Mahowald, N. M., Zender, C. S., Luo, C., Savoie, D., Torres, O. and co-authors. 2002. Understanding the 30-year Barbados desert dust record. J. Geophys. Res. 107, 4561, doi:10.1029/2002JD002097.

Malm, W. C., Pitchford, M. L., McDade, C. and Ashbaugh, L. L. 2007. Coarse particle speciation at selected locations in the rural continental United States. Atmos. Environ. 41, 2225-2239.

Marticorena, B. and Bergametti, G. 1995. Modeling the atmospheric dust cycle, 1: design of a soil derived dust production scheme. $J$. Geophys. Res. 100, 16415-16430.

Marticorena, B., Bergametti, G., Aumont, B., Callot, Y., N’Doumé, C., and co-authors 1997. Modeling the atmospheric dust cycle, 2: simulations of Saharan dust sources. J. Geophys. Res. 102, 4387-4404.

McKendry, I. G., Strawbridge, K. B., O’Neill, N. T., Macdonald, A.-M., Liu, P. S. K. and co-authors. 2007. Trans-Pacific transport of Saharan dust to western North America: a case study. J. Geophys. Res. 112, D01103, doi:10.1029/2006JD007129.

Meng, Z., Dabdub, D. and Seinfeld, J. H. 1998. Size-resolved and chemically resolved model of atmospheric aerosol dynamics. J. Geophys. Res. 103, 3419-3435.

Middleton, N. J. and Goudie, A. S. 2001. Saharan dust: sources and trajectories. Trans. Inst. Brit. Geographers 26, 165-181.

Myhre, G., Grini, A., Haywood, J. M., Stordal, F., Chatenet, B. and coauthors. 2003. Modeling the radiative impact of mineral dust during the Saharan Dust Experiment (SHADE) campaign. J. Geophys. Res. 108, 8579, doi:10.1029/2002JD002566.

Nickovic, S., Kallos, G., Papadopoulos, A. and Kakaliagou, O. 2001. A model for prediction of desert dust cycle in the atmosphere. $J$. Geophys. Res. 106, 18 113-18 129.

Nho-Kim, E.-Y., Michou, M. and Peuch, V.-H. 2004. Parametrization of size-dependent particle dry deposition velocities for global modelling. Atmos. Environ. 38, 1933-1942.

Nho-Kim, E.-Y., Peuch, V.-H., Lee, M.-J. and Oh, S. N. 2005. Parameterization of size-dependent particle gravitational settling for global atmospheric transport modeling. J. Korean Meteorol. Soc. 40, 523529.

Prospero, J. M. and Carlson, T. N. 1972. Vertical and areal distribution of Saharan dust over the western Equatorial North Atlantic Ocean. J. Geophys. Res. 77, 5255-5265. 
Reid, J. S., Kinney, J. E., Westphal, D. L., Holben, B. N., Welton, E. J., and co-authors. 2003. Analysis of measurements of Saharan dust by airborne and groundbased remote sensing methods during the Puerto Rico Dust Experiment (PRIDE). J. Geophys. Res. 108, 8586, doi:10.1029/2002JD002493.

Seinfeld, J. H. and Pandis, S. N. 1998. Atmospheric Chemistry and Physics: From Air Pollution to Climate Change. John Wiley and Sons Inc., New York, 408-451.

Sokolik, I., Winker, D. M., Bergametti, G., Gillette, D. A., Carmichael, G. and co-authors. 2001. Outstanding problems in quantifying the radiative impact of mineral dust. J. Geophys. Res. 106, 18 015-18 028.

Swap, R., Garstang, M., Greco, S., Talbot, R. and Kallberg, P. 1992. Saharan dust in the Amazon Basin. Tellus 44, 133-149.

Tegen, I. and Fung, I. Y. 1994. Modeling of mineral dust in the atmosphere: Sources, transport, and optical thickness. J. Geophys. Res. 99, $22897-22914$.
Thomson, M. C., Molesworth, A. M., Djingarey, M. H., Yameogo, K. R., Belanger, F. and co-authors. 2006. Potential of environmental models to predict meningitis epidemics in Africa. Tropical Med. Int. Health 11, 781-788.

Wexler, A. S., Lurmann, F. W. and Seinfeld, J. H. 1994. Modelling urban and regional aerosols, I, Model development. Atmos. Environ. 28, 531-546.

WMO. 1995. International Codes Volume I.1 Part C (Specification of Code Figures), WMO manual on codes. $\mathrm{N}^{\circ}$ 306, WMO, 139-143.

Zhao, T. L., Gong, S. L., Zhang, X. Y., Blanchet, J.-P., Mckendry, I. G. and co-authors. 2006. A simulated climatology of asian dust aerosol and its trans-pacific transport, part I: mean climate and validation. $J$. Clim. 19, 88-103.

Zender, C. S., Bian, H. and Newman, D. 2003. Mineral Dust Entrainment and Deposition (DEAD) model: description and 1990s dust climatology. J. Geophys. Res. 108, 4416, doi:10.1029/2002JD002775. 